\title{
ARIH1 Gene
}

National Cancer Institute

\section{Source}

National Cancer Institute. ARIH1 Gene. NCI Thesaurus. Code C134183.

This gene is involved in the ubiquitination of protein substrates. 